ANITA ORCHOWSKA*

\section{Standaryzacja w budownictwie mieszkaniowym w oparciu o przepisy prawa}

\section{Standardisation in housing construction based on legal regulations}

\section{Streszczenie}

W artykule przedstawiono rozwój i przemiany przepisów w zakresie Prawa budowlanego od początków jego funkcjonowania

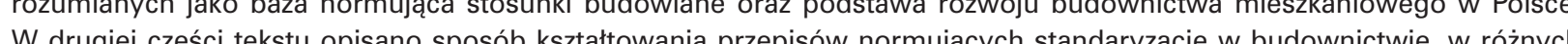
okresach rozkwitu mieszkalnictwa po II wojnie światowej do chwili obecnej. Szczególnie pochylono sie nad standardam i normatywami powierzchniowymi do projektowania mieszkań w zabudowie wielorodzinnej. Zwrócono szczególnie uwage na ich bezpośredni związek z jakością kształtowania mieszkań i cechami masowego budownictwa mieszkaniowego.

\section{Abstract}

This article presents the development and changes of the regulations regarding the Construction Law since the beginnings of its functioning, understood as the foundation for regulating the building connections and the basis for development of housing construction in Poland. The second part of the article describes how the law which regulated standardisation in housing construction was shaped in various periods of housing boom after World War II until now. The standards and floor paid to their direct connection with the quality of designing the flats and the been analysed closely. Particular attention was

Słowa kluczowe: Prawo budowlane, standardy, normatywy mieszkaniow
Key words: Construction Law, norms, housing standards

\section{Wprowadzenie}

Podstawą rozwoju budownictwa mieszkaniowego sa przepisy prawa budowlanego $\mathrm{i}$ regulacje powstate $\mathrm{n}$ jego bazie. Pierwsze unormowania w formie Prawa budow w czo wprowatzono w Polsce na począu $x x$ kedy wzrasi gaintowno

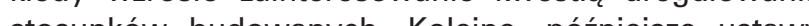
staty sie podwaling Prawa budowlonego obowiazuja cego od roku 1994 wraz z ustawa o zagospodarowaniu przestrzennym. Równolegle rozpoczeto w tym czasie poszukiwania standardów mieszkaniowych które poczatkowo zwiazane były z idea osiedli społecznych. Rozwój standaryzacij był podporzadkowany prawodawstwu tworzonemu przez administracje rzadowa, ale takż praktycznemu myśleniu o sytuacji mieszkalnictwa w Polsce. Normatywy projektowe ulegały ewolucji i zwiazane były ze zmieniajaca sie sytuacja polityczna i społeczna w kraju. Zmiany ram formalnych i norm projektowych przekładały się na konkretne rozwiązania architektoniczne i urbanistyczne zabudowy osiedli mieszkaniowych. Rozwiązania te były zróżnicowane. Dyskusja nad stan-

\section{Introduction}

basis for the development of housing construc tion are the legal provisions of the construction law and the regulations, which were created on its foundations. The first legal regulations in the form of the

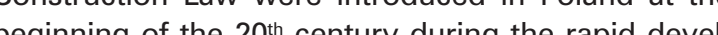
epment of construction industy, when the in develere er further acts taid the foundation for Construction aw, which have been adopted since 1994 togeth with the Act on spatial development. At the same time We search for housing standards began which initilly was connected with the idea of social housing. The development of standardisation was subordinated to legislation formed by the government administration but also practical thinking about the housing situation in Poland. The standards of design were evolving and were connected with changing political and social situation of the country. Changes in a formal frame work and design standards were reflected in specific rchitectural and urban solutions of residential devel- dardami mieszkaniowymi trwa także obecnie, a nowe jotycza calosci srodowiska zamieszkiwania i proponują rozwiazania dostosowane do nowe polityki społecznej miast w Polsce.

Wprowadzenie jednolitych przepisów, norm i zasad co do uporządkowanego oraz wielokrotnego stosowani wzorcôw, rozumiane jest jako standaryzacja. W zakresi budownictwa mieszkaniowego pojęcie standardu okresla pewien ustalony model, odnoszący się zarówno do warunków mieszkaniowych jak i potrzeb społecznych. Standaryzacja jest procesem, ktory charakteryzuje sie etapowością I zmiennoscią $w$ swoim przebiegu $\mathrm{i}$ jes bodżcem wzrostu jakości zamieszkiwania. Celem standaryzacji jest zmniejszenie liczby rozwązan i ograniczenie rożnorodnosci, a poprzez usprawnienie wykonawstwa jednak wciqz dyskusyiny wzolad estetyki objetego stanjednak weiaz dyskusyny waglad estetyki objętego stanPolemike moje wzbudzać róm prestz podaża co wciaż za standaryzacja kwestia normalizacji, masowej produkci oraz typologicznie programowanych rozwiazzán w zakresie budownictwa mieszkaniowego, tworzenie substandardu, co miało miejsce w przeszłości.

Przemiany w zakresie Prawa Budowlanego

W poczatkach $X X$ wieku w Polsce obowiazywało prawo byłych zaborców, na podstawie dekretu wydanego w roku 1919 przez Naczelnika Państwa' ${ }^{2}$. W roku 1928 wprowadzono $\mathrm{w}$ życie pierwsza polska ustawe Prawo budowlane zgodnie z Rozporządzeniem Prezydenta Rzeczypospolite ${ }^{3}$, ktora miała znamiona jednolitego prawa. Ustawa była obszerna i zawierała 422 artykuły, co wynikało objętości tematycznej regulacji w niej zawartych. Ustawa ta oparta była na wzorcu austriackim i obowiazywała przez 33 lata, co swiadczy o jej poprawności i uniwersalności, zwlaszcza jezeli chodzi o uregulowani procesu budowlanego, nadzoru i zagadnien przestrzennego rozwoju miast ${ }^{4}$. Poza tymi kwestiami znajdowaty się tu również zagadnienia z zakresu ustawy o planowaniu i zagospodarowaniu przestrzennym i dzisiejsze ustawy o gospodarce nieruchomościami, ochrony przeciwpozarowej, przepisów techniczno - budowlanych dla obiektow budowlanych, prawa lokalowego oraz praw cywilnego.

W kolejnych latach $1936^{5}$ i $1939^{6}$ wprowadzono drobne zmiany w ustawie, a nasteppnie $\mathrm{w}$ roku 1961 powołano w tré́cich byto wyodrebnienie zagadniń zagospodarowania przestrzennego i przeniesienie ich do ustawy o plana pru przestrzennym takie z roku 1961. Pozostawiono natomiast w Ustawie zagadnienia dotyczace procesu budowlanego. Ustawa wymagata stosowania przepisów techniczno - budowlanych, które miały byc uregulowane odrebnymi rozporzadzeniami oraz obowiazujacych norm państwowych. Określnie wymogu stosowania norm wraz z przepisami prawnymi nigdy nie było tak kategoryczne 8 jak w przywołanej Ustawie z roku 1961. Zawierała ona 96 artykułów i obowiazywała przez 14 lat, w czasie których doczekała sie dwóch nowelizacji. W zwiazku z coraz większym rozwojem budownictwa oraz zapotrzebowaniem na zmiany powołano w roku opments. These solutions were varied. The discus作 environment of living and offer solutions adjusted to a social policy of the cities in Poland.

Introducing consistent regulations, standards and rules related to structured and repeated use of models is understood as standardisation. When it comes to housing construction, the term standard defines a certain established model referring to both living conditions and social needs, too. Standardisation is the process characterised by stages and variability and is an incentive to increase the quality of living. The purpose of standardisation is to reduce the number of solutions and to limit variability. Also the improvement of construction would result in decreasing the costs of housing production. Still, there remains a disputable issue of aesthetics, which is embraced in construction standards and spatial solutions. The discussion may be also initiated due to the problem of standardisation mass production and typologically programmed solu-

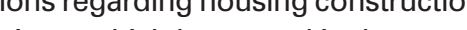
ations, which happened in the pas

\section{Changes in Construction Law}

At the beginning of the 20th century the law of exinvaders was in force in Poland, on the basis of the Decree publshed in 1919 by the Chief of State In 1928 the first Polish Construction Law Act was me the President of the Republic of Poland, which had some features or united law. This Act was comprea wive and cof uned 422 anliclos as in included wide range of topics of regullions. This act was b3 years, which confirms its correct bis ang for

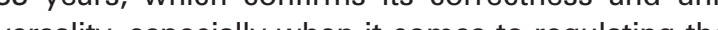
construction process, inspections and te issues of spatit development of the citiest. Apat from these sere other topics coved, which rehed to the Spail Development and Planing Act and the fire protection, technical and building regulations for building objects, tenant and civil law.

In the next years between $1936^{5}$ and $1939^{6} \mathrm{smal}$ chand the new Construction Law Act7 was adopted The main difference in the contents was extracting the is sues connected with spatial development and transferring them to the Spatial Planning Act which was also announced in 1961. The issues related to the construction process remained in the Construction Law Act. This Act required applying the technical and construction rules, which were supposed to be regulated by separate regulations and existing national norms. Establishing the requirement of using the norms together with legal regulations had never been so categoricals before as in the aforementioned Act of 1961. It included 96 articles and was in force for 14 years, during which two amendments were made. 
1974 kolejną Ustawę. Nie rozwiązała ona wielu problemow nawet w ramach wprowadzanych nowelizaci których w latach 1974-1990 było $9^{9}$. Generalnie ten ak prawny oceniany byla krytycznie zarowno przez uczes ników procesu inwestycyjnego, środowiska architektów, naukowców i organy administracyjne. Nieskutecznie okazały się obszary dotyczące organizacji nadzor budowlanego, kontroli i poziomu wykonawstwa, nisk sprawność instytucji uczestniczących w procesie inwestycyjnym. Błędem było zniesienie uzyskiwanych w drodze egzaminu uprawnień budowlanych i likwidacja państwowego nadzoru budowalnego. Dodatkowo znacznym niedoborem bylo brak dostosowania do zmian spoleczno-gospodarczych i wymagan gospodarki rynkowej, co nia te okazaty sie ja now relizacja z 1984 roku . Dzialaweszta w życie nowa obowizzujaca do dzisia ustawa Prawo budowlane11 dokonizumi io do dzisiaj ustawa ma nowelizacjami. Ustawa ta scalit wiele wstepnych opracowań projektowych ustawy wykonanych przez środowiska projektowe, naukowe i ministerialne. Należy zaznaczyć że równoczénie z nowym Prawem bu dowlanym weszła w życie Ustawa o zagospodarowani przestrzennych ${ }^{12}$ regulując wiele niejasności zwiazanych z miejscowymi planami zagospodarowania przestrzenzego, warunkami zabudowy i zagospodarowania teren oraz realizacją polityki przestrzennej państwa. Ustawa Prawo budowlane wprowadzita wiele zmian
w zakresie norm prawnych i procesu inwestycji budowlanych. Przede wszystkim wyodrębniła elementy projektowania, budowy obiektów i prowadzenia robót budowlanych, gdyż regulują je odrębne przepisy techniczno-budowlane i normy. Zastosowano obowiąze stosowania Polskich Norm zarówno w tekście Ustawy jak i w wydanym rozporządzeniu wykonawczym doty czącym warunkow technicznych jakim powinny odpowiadać budynki $i$ ich usytuowanie ${ }^{13}{ }^{14}$. Rozporządzenie zawarło stwierdzenie o obowiązkowosci stosowania załączonych w wykazie Polskich Norm.

W zakresie procesu inwestycji budowlanych Ustawa Prawo budowlane uregulowało rolę uczestników procesu budowlanego okreslając prawa i obowiązki, zwiększa jąc zakres ich odpowiedzialności, ponadto klarując kwestię kwalifikacji wprowadzajac obowiązkowy egzamin $n$ uprawnienia budowlane. Wzmocnila także i ujednolicila system państwowego nadzoru budowlanego. Nowa do regut oso Ustawa Prawo budowlane byta do chwili obecnej wie lokrotnie nowelizowana a odnóne rozporządzenie dotyczace warunków technicznych 9-cio krotnie w ciagu okresu od ich ogłoszenia ${ }^{16}$. Ten akt prawny nalez jednak rozpatrywać wraz z Ustawa o zagospodarowani przestrzennym, gdyż obie ustawy zmieniły stosunek do ganizacji procesu budowanego porzadkując $\mathrm{W}$ sposób znaczny te kwestie. Problemem Prawa budowlanego tkwi w tym, o czym pisza analitycy rynku budowlanego i środowiska naukowe, że wiele regulacji było w kolejnych nowelizacjach odmiennie wprowadzane i pozostawiały dezorientacje $w$ ich interpretacji. Podważa to sens
Due to a growing development of building industry and spite the adopted amendments ${ }^{9}$, nine of which were made between 1974 and 1990. In general, this law was criticized not only by the participants of the investmentprocess, but also by the architects' communities, scientists and administrative organs. The areas, such as coordination of building inspections, controls and the level of execution, low efficiency of institutions taking part in the investment process, turned out to be ineffective. It was a mistake to liquidate a building license obtained through the examination and national building inspections. Additionally, as there was a lack of adjustment to socio-economic Changes and requirements if the maket economy, a significant amendment was ins insficient and in 1905 a new Construction Law Act11, which still exists, was adopted. Throughout this time many amendments were made. This Act combined many initial drafts made by design, scientific and ministeria communties It must be noted that together with the Construction Law, a new Spatial Developmen Act $^{12}$ was implemented reguting many unclear issues related to local plans of spatial development tions of housing and area development and realisatio of spatial policy of the country.

The Construction Law Act introduced many changes regarding legal norms and the process of construction investments. First of all, it extracted the elements of designing, building objects and carrying out construction works since they are regulated by separate technical and construction codes and norms. It included a requirement to apply the Polish Standards in the context of the Act but also in the issued executory regulation concerning technical conditions, which should be adopted in the buildings and their location ${ }^{13}{ }^{14}$. This regulation contained the statement about dutifuness of obeying Polish Standards attached there. Regard ing the process of building investments the Construction Law Act regulated the role of participants of the construction process by defining rules and duties, increasing the extent of their responsibility, and, what's more, it clarified the issue of qualifications by introducing an obligatory examination to obtain a building license. It also strengthened and unified the system of national bulling inspections. This new Act adjusted the legal and institutional system to the rules of marke

The Construclion Law Act has been amended many thes so for and the regullion concerning technic was announced ${ }^{16}$. This legislation should be analysed wath the Spatial Development Act because both Acts changed their approach towards spatia housing development and the organisation of contruction process by regulating these issues in a sighificant way. The problem with the Construction Law Act, which is described by the market analysts and scientific communities, is that many regulations were implemented differently in the successive amend- dalszych nowelizacji i stwarza przesłanki do opracowania nowej Ustawy zawierającej opracowane rozwiązania kompleksowe, ktore uwzględnią interesy uczestnikow procesu budowlanego oraz właściwie rozumiany interes społeczny"

Obecnie spotykamy się z przekształcenie prawa i dostosowywanie przepisów do wymogów Unii Europejskie czyli implementacji unijnych dyrektyw na grunt polsk. Ponadto prowadzone są dyskusje spoleczne nad propozycją nowego Prawa budowlanego 2019 w którym isto ną kwestia jest uproszczenie procedur i ograniczenie biurokracjli, etapowośc projektów budowlanych, przypewnienie stabilności wydanych przez urzędy decyzji1'.

Przegląd przepisów normujących standaryzacje Przegląd przepisow normujących

Wtandard mirzkaniowy to norma lub wzorzec, kóry może odnosić sie do warunków mieszkanowych i stu żyć zaspakajaniu potrzeb spotecznych. W rozumieniu rzeczywistego poziomu warunków mieszkaniowych skrótowo można powiedzieć, że standard obejmuje aspekty zwiazane $z$ wiektościa mieszkania, wyposażeniem i wykończeniem oraz dotyczy sposób zabudowy i zagospodarowania terenu. Standard w odniesieniu do potrzeb społecznych to powiazzanie miejsca zamieszkania z niezbẹdnymi do życia częściami miasta, takim jak miejsce pracy i wypoczynku oraz dostepem obsługi handlowo - usługowej, edukacyjnej, kulturalnej oraz związany jest z charakterem sassiedztwa. Łạczy się również z rynkiem nieruchomości i jego funkcjonowaniem. Standardy mieszkaniowe ulegają ciągle przeobrażeniom zgodnie z nowymi potrzebami, ale także z uwagi na rosnące możliwości finansowe inwestorow. Analizując wstecz standardy można powiedziec, że poziom warunkow mieszkaniowych ulega ciąglej poprawie" . Ponižej przedstawiono przegląd przepisów normalizujących standardy mieszkaniowe z uwzględnieniem wskaźnik lokali mieszkalnych w budynkach wielorodzinnych.

Osiedle WSM i TOR - pierwsze (niepisane) standard mieszkaniowe

Początków standaryzacji należy szukać w okresie międzywojennym, kiedy to występowała olbrzymia społecz na potrzeba budowy duzej llości mieszkan dla likwidaci rezniejsym sposobem.

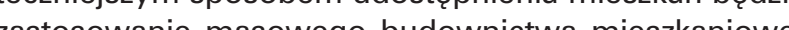
ao. Przyktadami sa osiedla spoteczne WSM ${ }^{20}$ (Warszawka Spótdzielnia Mieszkaniowa) na Żoliborzu i TOR 21 (Towarzystwo Osiedli Robotniczych) Za warszawskim Kole. Możemy mówić tu o idei polskiego osiedla opartego na założeniach funkcjonalizmu i zasadach programowani zgodnego z potrzebami ludności oraz doskonowan się form życia spotecznego. Osiedla wielorodzinne byty w szczególności dedykowane dla średnio i nisko zamoż nych warstw społecznych. Koncepcja urbanistyczn tych zespołów oparta była na pierwszym w Polsce ukła dzie liniowym, w przypadku zespołu TOR i blokowym półotwartym dla WSM. Układy budynków zapewniały ments and it made their interpretation confusing th undermines the idea of further amendments and pere are indications to draw up a new act including prepared complex solutions, which will take into account he interests of the participants of the building process and correctly understood social interest ${ }^{17}$. distaws 作 into the Polish, i.e. implementing the EU directives 作 is simplifiction of the procedures and rential issue bureaucry stages of building projects, actiction of the invest, stages of bulding projects, accelerailg stability of the decisions issued by the authorities ${ }^{18}$.

Review of the legal provisions regulating standardiation in residential construction

Housing standard is a norm or pattern which may reer to living conditions and serve to meet social needs. When it comes to understanding the real level of living conditions it might be said in short that the standard involves all aspects connected with the size of the flat furnishing and finishing and also refers to conditions of building development and land management. When the standard refers to social needs it involves some connection between the place of living with other vita parts of the city such as workplace or leisure centres, an easy access to commercial, educational and culthe character of the neighbourhood. It is connected with the real estate market and its functioning, too. The standards of living are undergoing constant changes following the new (be itivis of investors. Analysing the previous standard it might be said that the level of living conditions is constantly improving ${ }^{19}$. Below there is a review of legal provisions regulating the standards of living condtons and taking into account a surface indicator of the residential units in multi-family housing.

Residential estates of WSM and TOR - the first (unwritten) housing standards

The beginnings of standardisation should be searched for in the interwar period, when a huge in order to eliminate housing crisis. It was acknowt edged that the most effective way to make the flat available would be the implementation of large-scale rruction. Social residential estates such as WSM ${ }^{20}$ (Warsaw Housing Cooperative) in Zoliborz and TOR 21 (Workers' Estates Association) in Koto i Warsaw are such examples. We can talk here a the idea of a Polish residential estate based on functional assumptions and rules of programming which conform to people's needs and improve the forms of social life. Multi-family residential estates were especially dedicated to low and middle social classes. The urban concept of these residential complexe was based on the line layout in case of TOR complex 
podstawowe warunki higieny zabudowy, przewietrzania, doświetlenia i nasłonecznienia oraz obszerny program społeczny, ktory mial rekompensowac niedobory me trazowe lokali. W zakresie wielkosci powierzchniowych i rodzaju wyposażenia mieszkania w obu przypadkach stanowity (z dzisiejszego punktu widzenia) dolną granicę standardu mieszkaniowego ${ }^{22}$. Pomimo, że okresie międzywojnia nie funkcjonowały żadne przepisy regulujących standardy mieszkaniowe, to za ich określenie uważa się pierwsze warszawskie osiedla społeczne WSM I TOR. Lokale powstate $w$ ramach tych osiedli stanowity jedynie $5 \%$ oddanych do użytku mieszkan Wokr mie jedz 15,2 i 3 izbo W wały mieszkania $1,5,2$ i 3 izbowe o niskim standardzie i powierzchni $24-38 \mathrm{~m}^{2}$, dostosowane do małych moż w poczatkach swoj dziatności budowato mieszkania nie wieksze niz 32-36 m2 wosi budowalo mieszkania Był to pokói z wneka kuchenna przy czym jedna tazenka wspólna na pietrze była przeznaczona była dla kilku mieszkań24. Byly to jedne z pierwszych prób kiedy istota koncepcji projektowej podporzadkowanej spoteczne talityce mieszkaniowej stało sie zapewnienie goczne standardów mieszkanio stach.

\section{Kształtowanie się standaryzacji w okresie powojen-} nym aż do współczesności

W roku 1947 weszła w życie Ustawa o normach i standardach budowlanych ${ }^{25}$. Był to krótki dokument zawierający 10 artykułów $\mathrm{i}$ jako pierwszy prawny akt uściśla zagadnienie standardu. Ponadto ustawa definiowała co mogą określać normy i standardy w zakresie m.in. wytwórczości materiałów $i$ elementów budowlanych oraz projektowania I budowy budynków. Ustawa okreslał rownież to, że normy i standardy ustanawia Minister Odbudowy w porozumieniu z Wlasciwym ministrem. $\mathrm{Nie}$ pozostawiono jednak wątpliwości, ze normy i standardy są obowiązkowe oraz, że : „I...) standardy budowlane mogą określać minimalny i maksymalny poziom zaspakajania potrzeb w zakresie przestrzeni mieszkalnej i użytkowej oraz wyposażenia budynków(...)". Oprócz norm obowiązujących pojawiło się także pojęcie norm zalecanych.

Pierwsze standardy mieszkaniowe zostały opracowane w Instrukcji Ministerstwa Odbudowy z dnia 10 września 1947 roku. Przewidywały one "(...)5 podstawowych kategon mieszkaniowych, ktora byta okreslona wediug kładowo dla minimalnej powierzchni użytkowej loka $22 \mathrm{~m} 2$ minimum poj pown mieszkazej wynosit 16 m2 a dla maksymalnej powierzchni użtkowej $58 \mathrm{~m} 2$ i preferowanego rozwiazania 4 izbowego minimum powierzchni mieszkalnej to $40 \mathrm{~m}^{27}$. Konstrukcja tego standardu pozostawiała na niewielka swobode w rozwiazaniach pomieszczeń i podział ich na poszczególne wiaza takie jak: mieszkalne i niemieszkalne (tu: gospodarcze, komunikacyjne i sanitarne). Instrukcja normalizowała przestrzenie mieszkaniowe oraz precyzowała udział poszczególnych kategorii mieszkań w ogólnej liczbie lokali Nie było jednak powiązania $z$ wymiarami jakie wynikałaby $z$ uprzemysłowionych metod budownictwa ${ }^{28}$. W ma- the first one in Poland, and a block half-open layout in the WSM residential estate. The layouts of the buildtion provided the basic hygiene conditions, ventilaprogramme, sun exposure and an extended socia for the small sizes of the flats. As far as the sizes and types of flats' furnishing are concerned, in both and types of lats furnishing are concerned, in both cases standards (frented the bottom line ${ }^{22}$ when the living standards (from present perspective) are concerned. Despite the fact that during the interwar period there were not any legal provisions regulating the housing standards, their definition is included in the first social residential estates in Warsaw, known as WSM and TOR. The flats which appeared in theses estates made up only $5 \%$ of the delivered flats in the interwar period . In the Zoliborz estate (WSM) there were 1,5,2 and 3 bedroom flats of low standard with the floor space pacities of workers. At the beginning of its activity, the residential estate in Koto (TOR) constructed flats not bigger than 32-36 square meters in multifamily houses. It was a room with the kitchen and there was only one shared bathroom per floor designated for a few flats $^{24}$. These were the first attempts, when the key design concept was subject to social housing policy and was supposed to provide decent living standards.

\section{Development of standardisation in the post-war pe-} riod until contemporary times

In 1947 the Act on the Norms and Construction Standards was implemented ${ }^{25}$. It was a short document including ten articles and it was the first legal Act specifying the issue of standard. What is more, this Act clarified what regulations and standards may specify as far as the production of the building materials and elements, design and construction of the building are concerned. The Act made it clear that the norms and standards are defined by the Minister for Reconstruction in agreement with other responsible Ministers. There were not any doubts left that the norm and standards are obligatory and: '(..) construction standards may define the minimum and maximum level of meeting the needs as far as living space and floor area, finishing and furnishing of the buildings are concerned (...)'. Apart from the applicable standards, a concept of recommended standards appeared. The first housing standards were prepared in the Instruction of Reconstruction Ministry of 10 September 1947. They predicted '(...) five basic housing categories, which were defined according to the total floor floor are of a 22 square meter flat the minimum living space was 19 square meters and for maximum floor area of 58 square meters and preferabo solution of 4 bedroom flat the minimum living space was 40 square meters ${ }^{27}$. The construction of this standas 40 just a small flexibility in the arrangements of the rooms and their division for specific 'purposes' such as living and non-living (i.e. storage, passageway, sanitary) This instruction standardised living spaces and defined the participation of certain categories teriałach do dyskusji "Standardy Mieszkaniowe" Juliusz Goratynski pisze o tym, ze przewazająca ilosciowo kategorię lokali okreslono jako trzecią ${ }^{29}$, ktorej minimalny udział w ogolnej liczbie mieszkan powinien wynosic $60 \%$, a pozostatą ilość należy w równych częściach rozdzielić na mieszkania mniejsze i większe. Choć autor ocenił politykę mieszkaniową w zakresie standaryzacji jako znajdującą generalne potwierdzenie w rzeczywistosci, to już w roku 1951 okreslił błędy, które wynikały z „, bez dusznego lub doktrynerskiego stosowania instrukcji". Należaly do nich umieszczanie dużej liczby pomieszczen na małym limicie powierzchniowym, sztywne przepis dotyczace ilosci poszczegolnych kategorii wielkościotruktury lokali do zabudowy oraz zła polityka kwatern struktury lokali do zabudowy oraz zła polityka kwaterun-

roku 1949 uchwalono ustawę o utworzeniu Polskieo Komitetu Normalizacyjnego oraz o polskich normach Powołany Polski Komitet Normalizacyjn

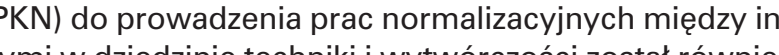
列 jednostką ustalającą Polskie Normy. Pr.awający nad Komitetem nadzór jest Przewodniczacy określenia norm i standardów obowiazujaccych na całym obszarze państwa lub pewnej jego części, lub dla pewnych gałęzi życia gospodarczego. $Z$ powyższego wyn$\mathrm{ka}$, że Polska Norma nie była obowiązująca. Natomias ustawa utrzymała $w$ mocy ustalenia $w$ zakresie norm budowlanych ${ }^{33}$. Następnie w roku 1953 powołano Dekret o normach i o Polskim Komitecie Normalizacyjnym ${ }^{34}$ ktory unieważnif obie wczesniejsze ustawy, wprowadzając jednocześnie normy zakładowe, resortowe i pan stwowe, obowiązujące na całym obszarze państwa oraz w okreslonych gałęzi gospodark

Kolejną zmianę w standardach wprowadzono w roku 1954, Uchwałą Prezydium Rządu w sprawie normatywów powierzchniowych dla projektowania w budown ctwie mieszkaniowym. Cztery lata pozzniej w roku 1958 skorygowano minimalnie wielkosci powierzchniowe mieszkań Zarządzeniem Prezesa Komitetu do Spraw Ur banistyki i Architektury w zakresie zmiany normatywów projektowy . Przewidywano wowczas 5 kategorii powierzchniowych. Dla przykladu, zgodnie z Zarządzeniem mieszkanie jednopokojowe powinno miec powierzchnie uzytkowa od $18-22 \mathrm{~m}^{2}$ jako jednopokojowe, a najwięk czym naibardziej poplane byly mieszkania o śedie czylkości od 41-50 ma duy lub trzy izbowe Przepisy dotyczace standaryzacii byty w tym czasie tagednie intepretowane w zwizku z potrzeba przyspiednenia procesów urbanizacii i budowy wiekszej ilości nowych mieszkań ${ }^{38}$. Potrzebne były zmiany w klosyfika ii mi kań objetych standardami, dlatego już w roku 1959 ggłoszono Uchwałe Rady Ministrów jako Normatyw projektowania mieszkań i budynków mieszkalnych wie lorodzinnych w miastach i osiedlach" ${ }^{\prime \prime 3}$. Wprowadzał on 7 typów mieszkań od M1 do M7, przy czym najmniejszy M1 o powierzchni od $17-20 \mathrm{~m}^{2}$, średni M3 o powierzchn od 33-38 $\mathrm{m}^{2}$ i M5 od 51-57 $\mathrm{m}^{2}$. Normatyw ustalał nowe wielkości standardu M6 i M7 do powierzchni 71 m² zmie- ber of dwellings. However, there was no reference to the sizes, which methods of construction . In the materials for discussion Housing Standards' Julusz Goratyhski wites that a predominant category of the dwellings was defined as the third one ${ }^{24}$, whose minimal participation in a to(t) remaining part 列 regarding standardisation as it had its general confirmation in reality, it was in 1951 when he listed the mistakes which resulted from 'heartless or doctrinal application of the instruction'. One of them concerned placing a big number of rooms on a small and limited floor area, another referred to strict regulations in the unber of certain size categories for the flats and lack to in roduce some other structus of the .

Act on formation of the Polish Commit ee for Standardization (PKN), Polish regulations and fords was implemented. The Polish Committe (PKN) was created to carry out works in the field of science and production and since then it became a body establishing Polish Standards ${ }^{31}$. The President of the National Committee for Economic Planning (PKPG) ${ }^{32}$ supervised the define the standards for the whole or some parts of the country, or certain spheres of economic life. Therefore, Polish Standards were not binding. On the other hand the Act upheld the decisions related to the standards of construction ${ }^{33}$. Later in 1953 the Decree on Standards and Polish Committee of Standards ${ }^{34}$ was implemen ed, which invalidated two previous acts and introduced company, departmental and national standards, which were legally binding in the whole country and also in specified branches of economy

Another change in standards was introduced in 1954 by virtue of the Resolution of the Presidium of the Government on floor space standards for desig in housing construction ${ }^{30}$. Four years later in 1958 a minimal floor space of the flats was corrected in the President's Regulation of the Committee on Ur ban Planning and Architecture regarding changes in design standards ${ }^{37}$. Five categories of the floor area were predicted then. For example, in accordance he fher Reg of 18 to 22 squore mat should have gest flat 59 to 66 square meters as a four the bigflat. The most popular flats were those of an aver age size between 41-50 square metres, two or thrbedroom flats. Regulations concerning standardisa tion were interpreted lightly in connection with the to great number of new flats ${ }^{38}$. Some changes were gorization of the flats which involved standards and thus in 1959 the Regulation of the Council of Ministers was announced as 'the standard for designing flats and multi-family housing objects in cities and residential estates ${ }^{39}$. It introduced 7 types 
niając $w$ tym czasie istniejące wielkości mieszkań normatywhych na mniejsze, co widoczne jest zwlaszcza w zakresie mieszkań średnich. Srednia wielkość mieszka zgodnie z tym normatywem wynosita $44 \mathrm{~m}^{2}$ powierzchn użytkowej jako obowiązująca w projektowaniu. Ustalono również, że powierzchniowa norma przewidziana n osobę powinna wynieść $w$ najbliższych latach przeciętnie $11 \mathrm{~m}^{2}$ powierzchni użytkowej.

W roku 1974 wszedł w życie nowo ustanowiony normatyw techniczny projektowania mieszkań i budynków mieszkalnych wielorodzinnych, zgodnie z Zarządzeniem Ministerstwa Gospodarki Terenowej i Ochrony Środowiska40, ktory powiązany był ściśle budownictwem powstajacym przy użyciu znormalizowanych elementów prefabrykwany. Za dolna granice stedniego stanizbe moina uzná $14 \mathrm{~m}^{2}$, co byto zgo we z no czasie na i ale taziez minimum spobylozo budownitwa caynszowego 41 . Zmniejszono kategorie mieszkń do 6 -ciu i powiekszono ich powierzchnie użytkowa. Przyktadowo dla lokalu M1 przewidziano od 25-28 m2 dla M3 byto to $44-48 \mathrm{~m}^{2}$, mieszkanie M5 to $65-70 \mathrm{~m}^{2}$, dla dla najwiekszego mieszknia 6 by określo wierzchnia dla największego mieszkania M6 była określona $\mathrm{w}$ gra-
nicach $75-85 \mathrm{~m}^{2}$. Choć wskaźniki powierzchniowe lokal nicach $75-85 \mathrm{~m}^{2}$. Choc wskazniki powierzchniowe lokal zodnie ze standardem uległy powiększeniu, to norma powodnie z prawem lokalowym z roku 1974 wynosiła od 7-10 $\mathrm{m}^{242}$. Mieszkania charakteryzowały sie $w$ dalszym ciągu ciasnotą, małymi łazienkami, ale równocześnie "jasnymi" kuchniami, co nie zawsze było uwzględnione w budynkach z lat 60 -tych. Wielkość i sposób zagospodarowania terenu, wokół budynków miała rekompensować aspekt powierzchniowy mieszkań, a przestronnośc zabudowy zapewniała dobre doswietlenie lokali. W czasie obowiązującego normatywu do roku 1985 powstato 3,5 min nowych mieszkan, co bylo rownoznaczne z wykonaniem $75 \%$ zakładanego przez panstwo planu w zakresie programów realizacji budownictwa wielorodzinnego ${ }^{43}$.

Po roku 1989 budownictwo mieszkaniowe było w głębokim kryzysie i rozwijało się $w$ niedostatecznej ilośc w stosunku do potrzeb społecznych. Pomimo prowadzonych $w$ tym czasie licznych dyskusji i badań klasy-
fikacyjnych, standardy mieszkań w zakresie normatywu fikacyjnych, standardy mieszkań $w$ zakresie
powierzchniowego nie uległy zamianom.

powierzchniowego nie uległy zamianom.
Po roku 2000 nastapił gwałtowny wzrost w budowniPo roku 2000 nastapif gwaltowny wzrost $w$ budowni-
ctwie, przy czym stare normatywy powierzchniowe przestały obowiązywać. Przyjęto, że istniejące Prawo budowlane i funkcjonujące przepisy techniczno-budowlane mają zabezpieczać użytkowników inwestycj mieskaniowych przed nieodpowiednimi rozwiazzaniami funkcjonalnymi, zapewnić bezpieczeństwo użytkowania i zagwarantować komfort rozwiazań przestrzennych. $z$ obserwacii wynika, że obecnie o standardzie mieszfinansowe i estetyczn preferencje przyszłych mieszkańców.

W roku 2018 wprowadzono nowelizacje do warunków technicznych, jakim powinny odpowiadać budynki i ich usytuowanie ${ }^{44}$, gdzie $\mathrm{W} \$ 94$ określono minimalna wiekość powierzchni użytkowej mieszkania w nowej zabudowie na $25 \mathrm{~m}^{2}$. Usunięto również minimalne wskaźnik of flats ranging from M1 to $M 7$, while $M 1$ had 17 to 20 meters and M5 had 51-57 square established a new size of M6 and M7 flats of 71 square metres changing at this time the existing sizes of the standard flats for smaller ones, which is especially seen in average flats. According to the standards the average size of the flats had 44 square meters of floor space and it was obligatory. It was also stated that the floor space norm per person should reach on average 11 square metres in the coming years.

In 1947 a new technical norm of designing flats and residential multi-family houses came into force in accordance with the Regulation of the Ministry for Local Economy and Environmental Protection ${ }^{40}$. It was clonstred with construction industry which of the average housing standard, which was applied th this time, was a room of 14 square meters, which complied with the standard and also with the minimum of the social and rental housing con 6 hection The category of the flats was reduced to 6 and their Theor space increar. For instadu was supposed to have 25-28 square meters, M3 44 48 square meters and M5 65-70 square meters. The floor area of the biggest flat known as M6 was defined to have 75-85 square meters. Although the surface in dicators of the flats in accordance with the standard increased, the norm of the floor space per one perso in line with the tenant law of 1974 ranged from 7 to 10 square meters ${ }^{42}$. The flats were still characterised by tightness, had small bathrooms, but at the same time 'light' kitchens, which was not always implemented in the buildings from the 60s. The size and the way of the area management around the buildings was supposed to compensate the size of the flats while the spatiality of the residential construction provided the flats with good lighting. Until 1985 when the norm was in force 3.5 billion of new flats was built, which meant com pleting $75 \%$ of the national plan as far as multi-family construction housing program was concerned ${ }^{43}$. After 1989 housing construction was in a deep crisis and was developing insufficiently in relation to socia needs. Despite numerous discussions, which were carried out at the time and classification research, the standards of the flats with regard to the floor are egulations were not change

After 2000 there was a boom in construction industry and the old standards were no longer binding It was accepted that the existing Construction Law are supposed to protect the users of the housing in vestments from inappropriate functional solutions, ensure the security of living and guarantes the comfort of spatial solutions. It is observed that nowaday financial possibilities and aesthetic preferences of the future dwellers determine the standard of flats. In 2018 the amendment to the technical conditions, which buildings should have and their location, was adopted ${ }^{44}$. In the Article 94 the minimum size of the floor space in a new residential development was de- szerokości pomieszczeń w świetle oraz zlikwidowano koniecznosc projektowania kawalerek z kuchnią na kozyśc aneksu kuchennego polączonego z pokojem. Daje to możliwośc więkzej elastyczności w projektowi i aranżacji wnętrz, zgodnie nowymi preferencjami odbiorcow zwlaszcza mieszkan małych.

Na podstawie opracowania Biura Architektury i Planowania Przestrzennego Urzędu m.st. Warszawy pt. "Osiedla Warszawy" wynika, że doszło do wykształcenia nieformalnego standardu, który jest „wypadkowa usrednionych preferencji klientów i efektywności ekonomicznej". W przypadku tzw.,"segmentu popularnego czyli lokalu najtańszego widoczna jest zasada budowy najwększej liczby pokoi przy wykorzystaniu minimalnego metrazu. Przytaczana publikacja Urzędu Miasta

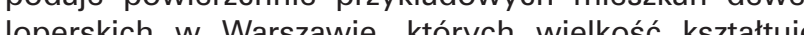
se najczésiej nastepujaco: najmniejse to kawalerk z a kzem kuchennym, których wiekość to kaw 30 $\mathrm{m}^{2}$ a najwieksze to mieszkania czteropokojowe $\mathrm{z}$ kuch nia o powierzchni do $87 \mathrm{~m}^{2}$. Najbardziej popularne sa jednak mieszkania dwu i trzy-pokojowe ${ }^{45}$. Typowym procederem jest również faczenie mieszkań na postawie tzw. zmian lokatorskich na etapie budowy czyli modyfikacji mieszkań, łączenie poszczególnych pomieszczen i zmiany rozkładu funkcjonalnego. Widoczne są również ciagle zmiany preferencji i podnoszenie wymaga użytkowników w zakresie komfortu zamieszkiwania i estetyki zabudowy.

\section{Podsumowanie}

ostatnim czasie standaryzacja w budownictwie mieszWriowym zatoczyla krag do poczatków okresu jej powstawania. Nie obowiązują szczegołowe normatywy projektowe, a na straży poprawnosci projektowej stoja przepisy Prawa budowlanego i odpowiednie rozporzadzenia. Okres funkcjonowania normatywów technicznych i projektowych to okres ksztattowania obniżonego standardu i braku odniesienia do indywidulanych potrzeb użytkowników, ale także machinalne podejści do tożsamości zabudowy i estetyki rozwiązań architektonicznych. To okres wpisywania się $\mathrm{w}$ aspekt spoleczny i koniecznosc masowego rozwoju budownictwa mieszk iowego. Standardy mieszkaniowe związane były najmocniej z okresem rozwoju budownictwa uprzemystowionego wytyczając ksztatt mieszkań i charakter stnieje mony zwiazek pomiedzy standaryzacia i rozwiazenia zich do unifikacii inwestycii mieszkaniowych. Wspótczesne mieszkalnictwo w Polsce nie zmierza w strone rozwiazań standardowych. Istnieje zatem potrzeba wypracowania odpowiedniego modelu lub wzorca cechujacego sie otwartościa na optymalne rozwiązania przestrzenn izarazem indywidualnościa w zakresie budowy podstaw wygodnej egzystencji oraz realizacji potrzeb mieszkaniowych Polaków.

PRZYPISY

Bilińnki T., Prawo budowlane wczoraj i dziś, w: Przegląd Budowlany, nt
2/2009, s. 24. fined as 25 square meters. An indicator of the width

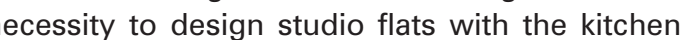
fovour of partial kitchen connected with the room. gives a possibility of bigger flexibility in interior design and arrangement in line with new prefer (

On the basis of the draft prepared by the Architectura Office and Department of Urban Planning of Municipa Office of the Capital City of Warsaw entitled 'Residential Estates of Warsaw' it may be concluded that an informal standard was created, which is the resultant of the average preferences of the clients and economic effice the che of a popular detached housing unit e. he bing flor ane The above mentioned publication of Municipal Office presents the exemplary floor spacto some flats in Warsaw, whose size is shaped as follows: a studio flat with partial kitchen is the smallest one and has 30 square meters and the biggest one of 87 squar meters is a four bedroom flat with the kitchen. However, the most popular are two and three bedroom flats ${ }^{45}$. A typical procedure also involves connecting flats on the basis of the so called tenant changes in the course of construction. It is a modification of the flats, by combining some rooms and making changes in the functional layout. There are visible constant changes in the preferences and increasing requirements of users with regard to living comfort and aesthetics of the residential development.

\section{Conclusion}

Recently standardisation in housing construction have come There are no obligatory and specific design standards and in order to make the designs correct there are regulations of the Construction Law Act and suitbe cal and design standards was the time when the lowered standard was developed and there was lack of

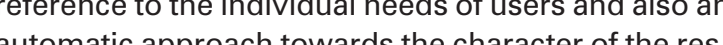
che solutions. This was the period when the social aspert and the necessity of mass deve 作 of living were very strongly connected with the peridiving we giving the shape of flats and character of the residential development. As can be seen from above there is a strong connection between standardisation and architectural solutions and it may lead to unification of construction investments. Contemporary housing in Poland is not moving towards standard solutions. Therefore, there is a need to develop an appropriate model or pattern featuring openness for optimal spatial solutions and at the same time the individuality tence and realization of the housing needs of Poles is concerned. 
2. Dekret Naczelnika Państwa Józefa Pitsudskiego z roku 1919 3 Rozporzadzenie Prezydenta Rzeczypospolitej z 16 lutego 1928 o prawie budowlanem i zabudowaniu osiedli (Dz. U. R. P. Nr 23 poz. 2022.
4 Biliński, T., Prawo budowlane wczoraj i dziś, w: Przegląd Budowlany, nr 2/2009, s. 25.

- Ustawa z dnia 4 lipca 1936 r. o zmianie rozporzadzenia Prezydeni zabudowaniu osiedli (Dz.U. Nr 56, poz.405). 6 Dekret Prezydenta Rzeczypospolitej z dnia 25 sierpnia 1939 o zmianach rozporzadzenia Prezydenta Rzeczpospolitej o prawie
budowlanym izabudowaniu osiedli (Dz.U. . 1939 r. . 7 7. poz. 514 )
7 Ustawa z dnia 31 stycznia 1961 r. Prawo budowlane (Dz. U. Nr 7 . ? Ustawaz z dnia 31 stycznia 1961 r. Prawo budowlane (Dz. U. Nr 7.
poz. 46).

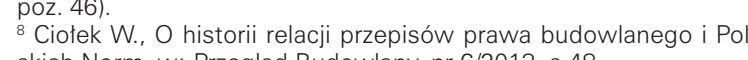

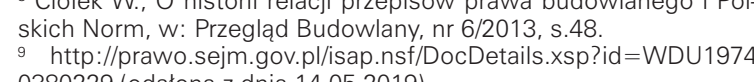

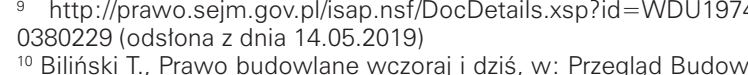
10 Biliński T., Prawo budowlane wczoraj i dziś, w: Przegląd Budow lany, nr 2/2009, s. 26.
11 Ustawa z dnia 7 lipca 1994 r. Prawo budowlane (Dz. U. Nr 89. poz. 414).
12 Ustawa z dnia 7 lipca 1994 r. o zagospodarowaniu przestrzennym (Dz. U. Nr 89, poz. 415).
13 Rozporzadzenie Ministra Gospodarki Przestrzenneji Budownictwan z 14 grudnia 1994 W sprawie warunków technicznych, jakim powin-
ny odpowiadac budynki i ich usytuowanie (Dz. U. Nr 10, poz.46). 14 Ciotek W., O historii relacji przepisós prawa budowlanego i Pol-
skich Norm, w. Przeglad Budowlany nr 62013 s. 49 . skich Norm, w: Przeglad Budowlany, nr 6/2013, s. 49.
${ }_{15}$ Biliński T., Prawo budowlane wczoraj i dzis, w: Przegląd Budow-

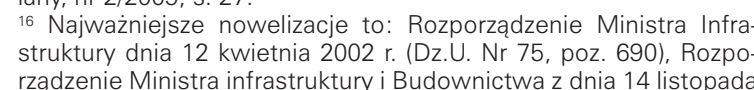
2017 r. zmieniajajce rozporzadzenie $w$ sprawie warunków technicz-
nych, jakim powinny odpowiadać budynki i ich usytuowanie ( $D z$. $U$. 2017, poz. 2285).
17 Nowakowski A. B. Pierwsze polskie prawo budowlane a praw

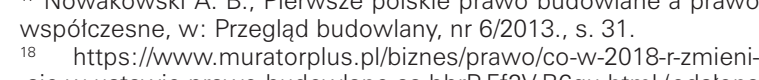

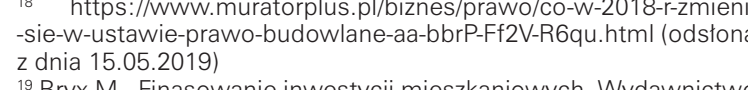

19 Bryy M. Finasoowanie inwestycji mieszkaniowych, Wydawnictwo
Poltext Warszawa 2001 s. 27 Poltext, Warszawa 2001 , s. 27.
${ }_{20}$ Rozpoczęcie budowy 1925 rok, do roku 1939 powstato IX Kolon mieszkalnych.
21 Realizacia w latach 1935-38

22 Woitkun G., Wielorodzinne budownictwo mieszkaniowe w Pol-
sce. W cieniu wielkiej ptyty. W: Przestrzeń i Forma nr 10/2008, ${ }_{23}$ Shttps://architektura.um warszawa pl/sites/default/files/files/Pub kacia. Osiedla_Warszawy O.pdf (odstona z dnia 16.05.2019).
24 http://www.iwaw.pl/obiekt.php? $=562066328$ (odstona z dnia ${ }^{24}$ http: / / wWw. Wwaw.pl/obiekt.php? $=562066328$ (odstona z dnia
${ }_{25} .0 .2019$ ) 25 Ustawa $z$ dnia 3 lipca 1947 r. o normach i standartach budowr-
nych.(Dz.U. nr 52 , poz. 269).

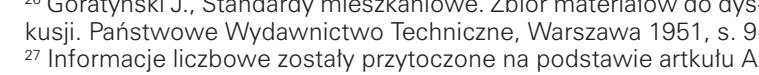
Nadolnego "Normatyw mieszkaniowy w odniesieniu do zabudowy

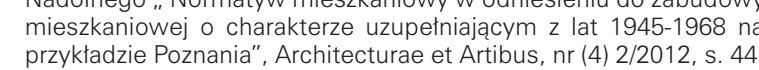
przykladzie Poznaniaa", Architecturae et Artibus, nr (4) 2/2012, s. 44 .
28 Ibidem, s.10. 29 Przewidywata ona dla powierzchni użytkowej $41 \mathrm{~m} 2$ minimum
powierzhni mieszkalnej $28 \mathrm{~m} 2 \mathrm{i}$ rozwiazania do ilości 3-ch izb.

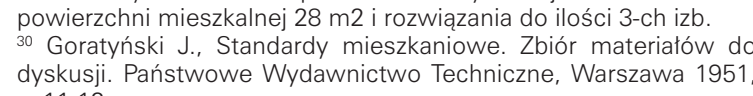
dyskusl. Panstwowe Wydawnictwo Techniczne, Warszawa 1951 ,
s. 11,12 .
3i stawa z dnia 20 grudnia 1949 r. o utworzeniu Polskiego Komite-
tu Normalizacji oraz polskich normach i standardach (Dz.U. nr 63, poz. 493).
32 Państwowa Komisja Planowania Gospodarczego

${ }_{33} \mathrm{~h}$ https://www. pkn.pl/informacije/2018/11/jak-kszatltowala-sie-polska-normaliza.
$17.05 .2019)$.

${ }_{34}^{34}$ Dekret $z 4$ marca 1953 r. (Dz.U. nr 15, poz.61)
${ }_{35}$ Ciotek W O hist

skich Norm, w: Przegladd Budowlany, nr 6/2013, s. 48 . 列 Zatwierdzenia normatywow projektowania dla budownictwa miesz-
kaniowego (.P.n 120 poz. 16888 .
37 Zarzadzenie Prezesa Komitetu do Spraw Urbanistyki i Architektu37 Zarzadzenie Prezesa Komitetu do Sraw
ry dnia 6 maja 1958 r. W s sprawie zmiany normatywów projektow
Bilińnki T., Construction Law Yesterday and Today, Building Review, no

Decree of Józef Pitsudski, the Chief of State, 1919 (Journal of Law of 7 ebruary 1919, No. 14, item 176). Regulation of the President of the Republic of Poland of 16 February
1928 on Construction Law and Housing Estate Development (Journal

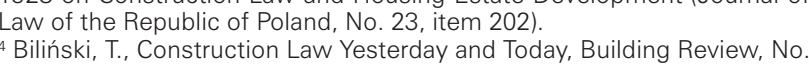
2/2009, p. 25 .
" The Act of 14 July, 1936 amending the Regulation of the President the Republic of Poland of 16 February, 1928 on Construction Law and Decree of the President of the Republic of Poland of 25 August, 1939 amending the Regulation of the President of the Republic of Poland on al of Law, No , item 46). Ciofek W., About the History of Retion

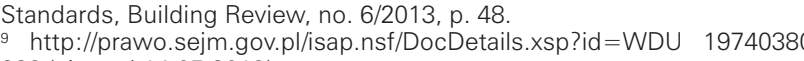
229 (viewed 14.05.2019)

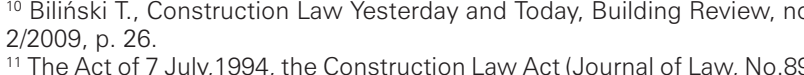

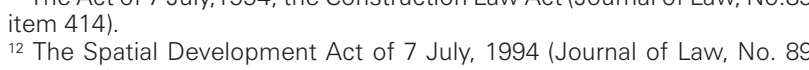
${ }_{13}$ Regulation of the Minister for Spatial Development and Construction of 14 December 1994 on technical conditions which should be obeyed in case of buildings and their locations Journal of Law, No.110, item 46).
14 Ciotek W.. About the History of Relations of Construction Law and Polish Standards, Building Review, no. 6/2013, p. 49.
${ }_{15}$ Bilinhski T., Construction Law Yesterday and Today, Building Review, no.

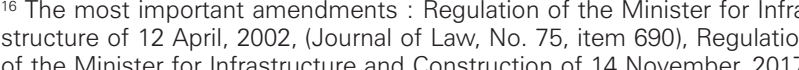
amending the Regulation on technicical condititions which should be of buildings and their locations (Journal of Law of 2017, item 2285 .
in Nowakowski A. B., First Polish Construction Law and Contemporar
Law, Building Review, no. 6/2013, p. 31.

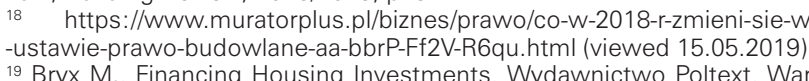

szawa 2001, p. 27.
22 Construction started in 1925, 9 colonies were built until 1939
21 Realization in the years $1935-38$.

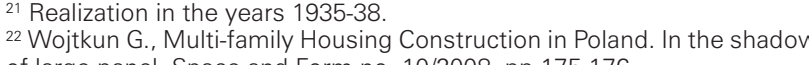
of large panel. S. Sace and Form no. 10/20008, p. $175-176$.
23

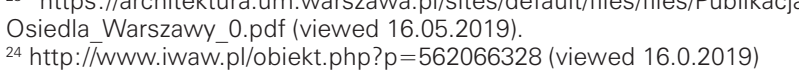

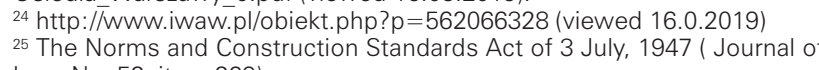
Law, No. 52, item 269).

26 Goratýńti J., Huosing Standards. Collection of materials for discus-
sion. Pansistwowe Wydawnictwo Techniczene. Warszawa 1951 . sion. Państwowe Wydawnictwo Techniczne, Warszawa 1951, p. 9 .
${ }_{27}$ The figures were cited from the article of A. Nadolly 'Housing standar ds in reference to housing developments of complementary type in the (4) 2/2012, p. 44 .
(2) the example of Poznań', Architecture et Artibus, no. ${ }_{28}$ Ibidem, p. 10

It predicted $41 \mathrm{~m} 2$ of living space for the floor area of $28 \mathrm{~m} 2$ and solu
jons not exceeding 3 rooms

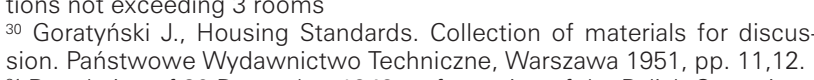

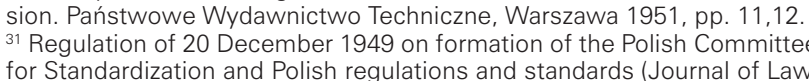
for Standardization and Polish regulations and sta
No. 63, item 493).

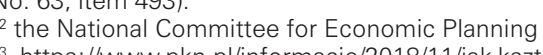

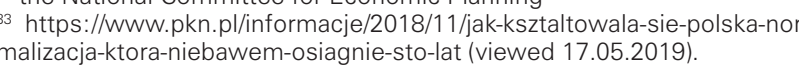

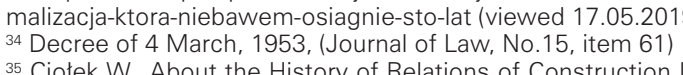

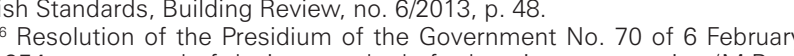
1954 on approval of design standards for housing construction (M.P.Po. 37 the President's Regulation of the Committee on Urban Planning and Architecture of 6 May 1958 on changes in design standards in housing
construction (M.P. no. 41 , item 237). 38 Nadolny A. Housing standard in reference to housing development of
complementary type from $1945-1968$ on the example of Poznan, Archi-
38 Nadolny A.e Normatyw mieszkaniowy $w$ odniesieniu do zabudowy
mieszkaniowej o charakterze uzupetniajacym $z$ lat $1945-1968$ na przykta dzie Poznania, Architecturae et Artibus, nr (4) 2/2012,s.44. sa Uchwata nr 364 Rady Ministrów $z$ dnia 20 sierpnia 1959 r. w sprawie
zatwierdzenia normattwwów projektowania dla budownictwa mieszkaniowego (Dz.U. nr 81, poz. 422).
0 Zarzadzenie nr 10 Ministerstwa Gospodarki Terenowej i Ochrony Środowiska $z$ dnia 29 stycznia 1974 r. $w$ sprawie ustanowienia normatyw

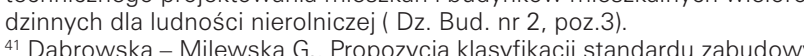
"Dieszkaniowej wielorododzinneje powstatejej w Polsce po roku 1990, Problemy miezzkaniowe wielorodzinneej powstalejw
Rozwoju Miast 4/3, 2007, p. 59,61.

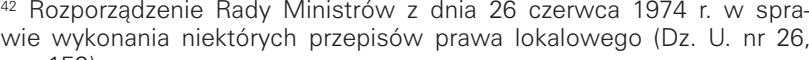
poz. 152).

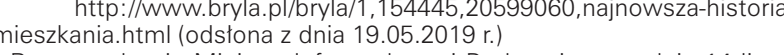
${ }_{44}^{-m i e s z z a n a r i a h t m n}$ Rozpodsadzenie Ministra Intrastruktury i Budownictwa z dnia 14 listopada 2017 r.zmieniajajce rozporzadzenie w sprawie warunków technicz-
nych, jakim powinny odpowiadać budynki i ich usytuowanie (Dz.U. 2017 nych, jakim powinny odpowiadac budynki i ich usytuowanie (Dz.U. 2017
poz. 2285). ${ }^{45}$ https:///architektura.um.warszawa.pl/sites/default/fill
Osiedla_Warszawy_0.pdf (odstona z dnia 16.05.2019).

LITERATURA

1] Biliński T., Prawo budowlane wczoraj i dzis, w: Przeglad Budowlany 2] Bry M. M., Finasowannie inwestycji mieszkaniowych, Wydawnictwo Poltext, Warszawa 2001
[3] Ciotek W., O historii relacii przepisów prawa budowlanego i Polskich Norm, w: Przeglad Budowlany, nr 6/2013, s. $46-50$

(4) Dabrowska-Milewska G., Propozycija klasyfikacij standardu zabudowy my Rozwoju Miast 4/3. 2007, p. 56-65 [5] Goratýnski J., Standardy mieszkaniowe. Zbiór materiatów do dyskus.

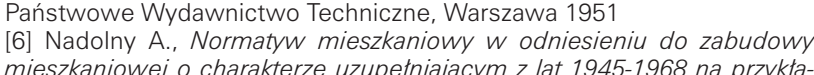

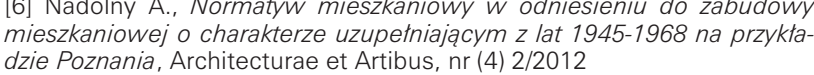
[7] Nowakowski A. B., Pierwsze polskie prawo budowlane a prawo wspót

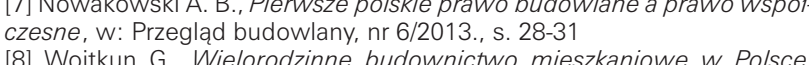

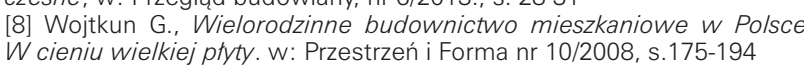

\section{INNE ŻRÓDtA INFORMACJ}

11] hittps:///architektura.um. warszawa.pl/sites/default/files/files/Publika

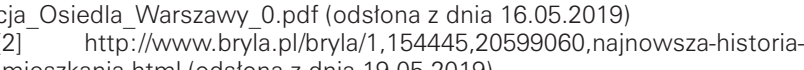

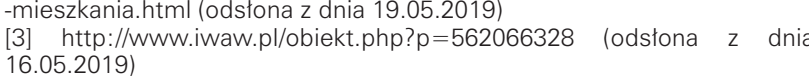

[4] h.tp://prawo.sejm.gov.p///(odsłona z dnia. 16.05.2019
39 Regulation No. 364 of the Council of Ministers of 20 August,
1959 on aporoval of design standards for housing construction (Journal of Law no 81 item 422 ! Regulation No. 10 of the Ministry for Local Economy and Enyhorms of designing flats and multit-family building shing technic agricultural population (Building Journal , no. 2, item.3).
$\star 1$
4 Dabrowska - Milewska G., Proposition of classification

Dabrowska - Milewska G., propostition ch classification of standards for multi-family housing development created in Polann after
1990 , The problems of development of the cities $4 / 3,2007$, pp.

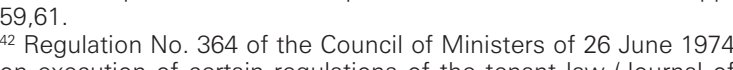
on execution of certain regulations of the tenant law (Journal of

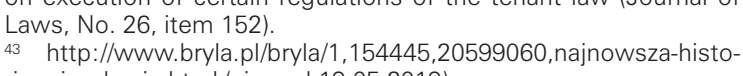
ria-mieszkania.hthl (viewed 19.05.2019) ${ }^{44}$ Regulation of the Minister for Infrastructure and Construction
of 14 November 2017 changing the regulation on technical conditions required for
of 2017 , item 2285 .

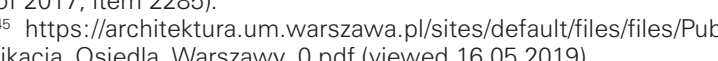

\section{BIBLIOGRAPHY}

Construction Law Yesterday and Today, Building Re view, no. 2/2009, pi. 24-29
[2] Bry M. Financing Housing Investments, Wydawnictwo Poltext, [3] Ciotek W. About the History of Relations of Construction Law
and Polish Standards, Building Review, no. 6/2013, pp. 46-50 and Polish Standards, Building Review, no. 6/2013, pp. 46-50
[4] Dabrowska-Milewska G. Proposition of classification of standards for multi-family housing development created in Poland after
1990 . The problems of development of the cities 4/3, 2007, pp. ing standards Collection of the waterits for Goratynski. ., Housing standards. Collection of the materials
for discussion. Państwowe Wydawnictwo Techniczne, Warszawa 1951 Nadolny A., Housing standards in reference to housing deve-
[6] Nopments of complementary type in the years $1945-1968$ on the

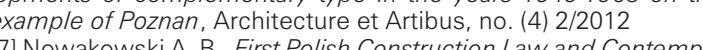
ary Law, Building Review, no. 6/2013. pp. 28-31 [8] Wojtkun G., Multit-amily Housing Construction in Poland. In the
shadow of large panel. Space and Form, no. 10/2008, pp. 175-194

\section{OTHER SOURCES OF INFORMATION:}

11] https:///architektura.um.warszawa.pl/sites/defaultfilies/files/

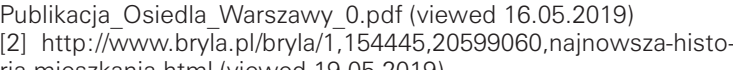
3] http://www iwaw.pl/obiekt.php?p=562066328 (viewed [4] hittp://prawo.sejm.gov.p//(viewed 16.05.2019) 